\title{
ANALISIS KARAKTERISTIK DEBIT PADA DAS TUNUO, KECAMATAN TOBELO BARAT KABUPATEN HALMAHERA UTARA
}

\author{
Ronald Kondolembang \\ Program Studi Kehutanan Universitas Halmahera \\ Kampus UNIERA Komplek GMIH Wari Ino Tobelo, Halmahera Utara, 97762 \\ Penulis Korespondensi Email : klronald4@gmail.com
}

Diterima : 1 Juni 2016

Disetujuai : 1 Agustus 2016

\begin{abstract}
Intisari
Debit aliran merupakan laju aliran dalam bentuk volume air yang melewati suatu penampang melintang sungai per satuan waktu. Data debit atau aliran sungai merupakan informasi yang paling penting bagi pengelola sumber air, karena mengingat kebutuhan air oleh masyarakat tergantung dari jumlah ketersediaan air pada suatu DAS terutama pada musim kemarau. Penelitian ini bertujuan untuk mengetahui karakteristik debit aliran pada DAS Tunuo yang bermanfaat untuk perencanaan pengelolaan air yang berkelanjutan. Penelitian ini dilakukan dengan cara pengukuran langsung debit aliran pada DAS dengan tahapan - tahapan yaitu pengukuran profil sungai, pengukuran kecepatan aliran serta pengamatan secara langsung tentang kondisi iklim. Analisis yang digunakan menggunakan analisis Hidrograf Debit yang menjelaskan jumlah waktu yang dibutuhkan debit untuk meningkat pada suatu kejadian hujan tertentu serta menggunakan parameter kondisi biofisik DAS yaitu topografi, jenis tanah serta kondisi penutupan lahan. Karakteristik debit berdasarkan hasil analisis hidrograf menjelaskan mengenai waktu naik debit setelah kejadian hujan menjadi debit puncak pada DAS Tunuo membutuhkan waktu selama 5 jam sedangkan waktu dasar (base time) adalah sekitar 16 jam, hal ini terjadi karena peranan faktor biofisik DAS Tunuo berperan dalam menghambat aliran air hujan seperti kondisi topografi DAS yang dominan datar dan landai serta penutupan vegetasi masih dominan hutan dan kebun campuran.
\end{abstract}

Kata Kunci : Curah hujan, Daerah aliran sungai, Debit, Tobelo

\begin{abstract}
The flow rate of watershed is in the form of volume flow rate of water through a river cross section per unit time. Data discharge or flow is the most important information for the management of water resources, as given by the community water needs depend on the availability of water in a watershed, especially in the dry season.This study aims to investigate the characteristics of flow in the watershed of Tunuo and it is useful for the planning of sustainable water management. This research was carried out by means of direct measurement of the flow rate in the watershed with the stage as follows: measurements of the river profile and flow rate as well as direct observation of the climate conditions. The analysis used using Debit hydrograph analysis that describes the amount of time required for the discharge is increased in a particular rain event as well as the use of biophysical parameters i.e. watershed topography, soils and land cover conditions .Discharge characteristics based on the analysis of hydrograph explain the rise time discharge after rain event into the peak discharge in the Tunuo watershed takes over 5 hours while the time (base time) is about 16 hours. This is due to the role of biophysical factors of the Tunuo watershed in inhibiting the flow rainwater as dominant topography of watershed (flat and sloping)and also forest vegetation cover and mixed farms is still dominant.
\end{abstract}

Keywords : Debit, Rainfall, Tobelo district, Watershed 


\section{PENDAHULUAN}

Daerah Aliran Sungai (DAS) merupakan suatu wilayah daratan yang dibatasi oleh topografi alami yang berfungsi menampung, menyimpan dan mengalirkan air hujan melalui sungai menuju outlet sungai tersebut. DAS memiliki karakteristik spesifik yang sangat menentukan respon DAS terhadap curah hujan yang jatuh di wilayah DAS tersebut. Karakteristik spesifik DAS berkaitan dengan jenis tanah, topografi, kemiringan, panjang lereng dan campur tangan manusia dalam pengelolaan lahan. Respon DAS akan mengalami perubahan jika karakteristiknya mengalami perubahan juga.

Karakteristik debit aliran pada suatu DAS sangat dipengaruhi oleh faktor curah hujan dan juga sifat fisik dari DAS tersebut. Kondisi fisik DAS yang sangat berperan penting terhadap karakteristik DAS adalah faktor tanah dan vegetasi pada wilayah DAS sehingga apabila terjadi perubahan pada kedua faktor tersebut maka berubah pula karakteristik debit pada DAS tersebut. Dengan demikian informasi tentang bagaimana kondisi karakteristik debit pada suatu DAS dapat menjelaskan sejauh mana kondisi fisik DAS yang bersangkutan. Selain itu informasi tentang kondisi debit pada suatu DAS sangat diperlukan untuk mengetahui potensi sumberdaya air pada di suatu wilayah DAS sehingga perencanaan pengelolaan air dapat berlangsung dengan efektif.

Berdasarkan data mengenai tingkat kekritisan lahan pada wilayah DAS di Halmahera Utara yang dikeluarkan oleh BPDAS Ake Malamo (2011), pada wilayah Halmahera Utara memiliki lahan yang agak kritis sebesar 306.612 Ha, lahan kritis sebesar 100.555 ha, lahan yang berpotensial kritis sebesar 157.890 ha, dan lahan yang sangat kritis sebesar 17.777 ha. Hal ini disebabkan adanya kegiatan konversi lahan oleh masyarakat untuk dijadikan lahan pertanian dan lahan pemukiman sehingga dapat merusak fungsi h i d r o l o g i s D A S. In f or $\mathrm{m}$ a s i m e $\mathrm{n}$ g e $\mathrm{n}$ a i karakteristik debit sangat penting dalam upaya pengelolaan sumber daya air yang bersinam-bungan dalam skala DAS.

Berdasarkan kondisi tersebut, apabila tidak segera ditangani dikhawatirkan menimbulkan krisis sumberdaya lahan (tanah) dan air yang lebih parah lagi di masa yang akan datang. Untuk maksud tersebut, perlu dilakukan penelitian untuk mengetahui bagaimana karakteristik debit sungai pada Daerah Aliran Sungai Tunuo, sehingga dengan hasil tersebut dapat menjadi bahan informasi yang penting dalam pengelolaan sumber daya air yang baik pada wilayah DAS

\section{METODE PENELITIAN}

Metode yang digunakan dalam penelitian ini adalah metode deskriptif kuantitatif terhadap hasil pengukuran langsung parameter debit. Pengukuran terhadap debit dilakukan dengan menggunakan alat Current Meter dan dilakukan dilakukan setiap hari pada pukul 08.00, pukul 12.00, pukul 16.00.

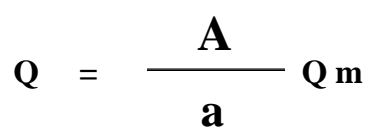

Dimana :

$$
\begin{aligned}
\mathrm{Q} & =\text { Debit }\left(\mathrm{m}^{3} / \mathrm{det}\right) \\
\mathrm{A} & =\text { Luas Penampang Sungai }\left(\mathrm{m}^{2}\right) \\
\mathrm{a} & =\text { Luas penampang alat pengukur } \\
& \left(0,000177 \mathrm{~m}^{2}\right) \\
\text { Qm } & =\text { Debit pada meteran alat ukur } \\
& \left(\mathrm{m}^{3} / \mathrm{det}\right)
\end{aligned}
$$

Hasil pengukuran debit dan curah hujan dibuat dalam bentuk grafik hidrograf debit. Hidrograf debit menggambarkan karakteristik debit dalam satu hari berupa waktu naik (Tp) menjadi debit puncak (Qp) dan waktu dasar (Tb) dalam suatu kejadian hujan.

\section{HASIL DAN PEMBAHASAN}

\section{Bentuk Profil dan Penampang Sungai}

Daerah Aliran Sungai (DAS) memiliki karakteristik yang berbeda-beda, perbedaan ini banyak ditentukan oleh beberapa faktor, antara lain: bentuk dan ukuran DAS, pola drainase serta profil melintang dan gradient memanjang sungai yang sangat mempengaruhi debit sedimen yang terjadi pada DAS tersebut (Sosrodarsono dan Takeda, 1980). Menurut Mangundikoro (1985) air merupakan salah satu unsur ekosistem DAS yang berkaitan erat dengan unsur lainnya, sehingga dapat mempelajari karakteristik unsur - unsur lainnya dan dapat dipergunakan untuk memprediksi karakteristik airnya.

Berdasarkan hasil pengukuran penampang melintang DAS Tunuo pada 2 titik yang berbeda, menunjukkan bahwa terjadi perubahan bentuk penampang sungai, yang akan mempengaruhi debit aliran pada DAS Tunuo. Bentuk penampang pada titik 1 dan 2 dapat dilihat pada Gambar 1 dan 2. Berdasarkan Gambar 1. menunjukkan bahwa bentuk profil melintang sungai Tunuo berbentuk parabola. Luas penampang sungai berdasarkan hasil perhitungan menunjukkan nilai $7,70 \mathrm{~m}^{2}$. 
Pengukuran pada titik 2 dengan selisih jarak adalah $100 \mathrm{~m}$ dengan tujuan untuk melihat apakah terjadi perubahan profil penampang sungai pada DAS dapat dilihat pada Gambar 2. Berdasarkan Gambar 4, bahwa bentuk profil sungai pada DAS Tunuo tidak mengalami perubahan bentuk yaitu bentuk parabola dengan luas penampang adalah $6.44 \mathrm{~m}^{2}$. Hal ini menggambarkan bahwa tidak terjadi perubahan kecepatan aliran sungai yang ekstrim atau dapat dikatakan kecepatan aliran stabil. Faktor - faktor yang bisa mempengaruhi perubahan bentuk penampang sungai adalah perubahan kecepatan aliran yang ekstrim sehingga terjadi gesekan dibawah permukaan sungai, kemudian pengaruh sedimen yang terbawa oleh sungai dalam jumlah yang besar, walaupun ada sedimen yang terbawa namun pengaruhnya tidak terlalu ekstrim serta pengaruh vegetasi sekitar lokasi pengukuran berfungsi dengan baik dalam menghambat laju run off sehingga tidak terjadi perubahan bentuk penampang sungai.

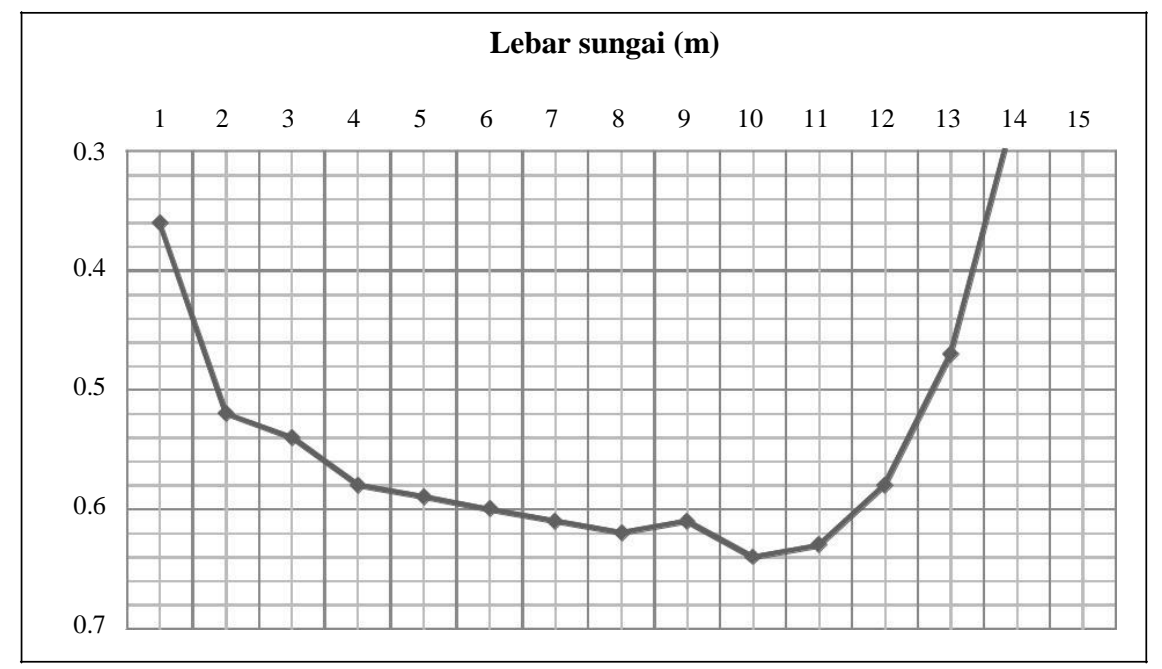

Gambar 1. Bentuk Penampang Sungai Pada Titik I

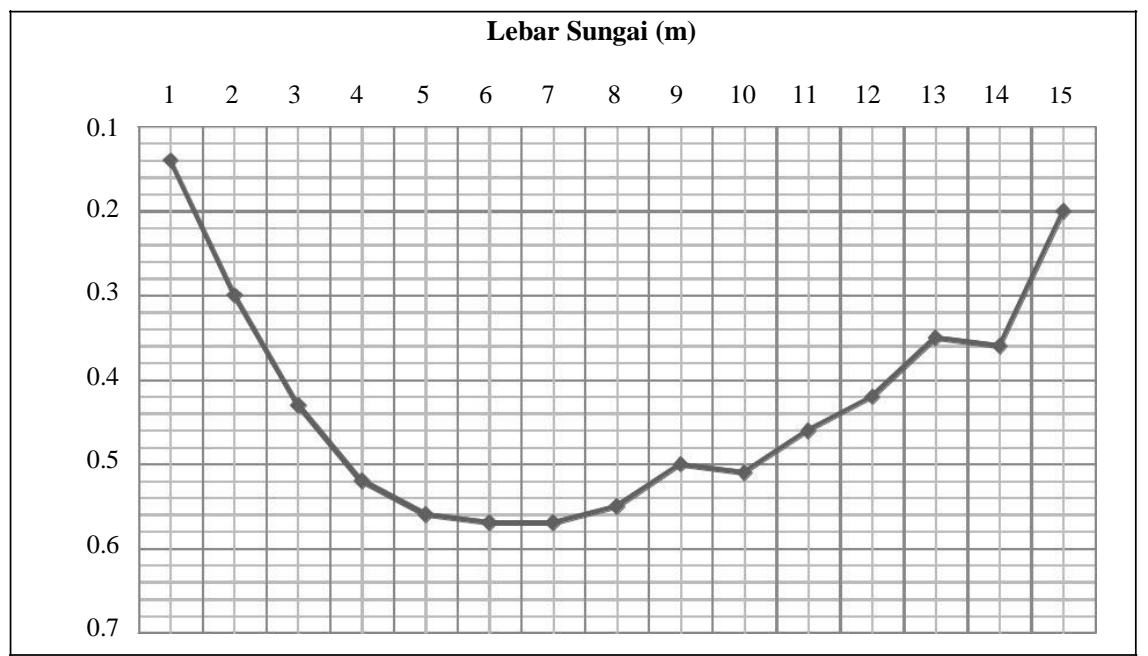

Gambar 2. Bentuk Penampang Sungai Pada Titik 2

\section{Karakteristik Debit DAS Tunuo}

Berdasarkan hasil perhitungan terhadap data hasil pengukuran kecepatan aliran (V) dan luas penampang sungai (A), maka diperoleh hasil pergerakan debit (Q) harian pada DAS Tunuo dan dapat dilihat pada Gambar 3. yang menunjukan bahwa terjadi peningkatan debit ketika terjadi hujan, yaitu pada pengukuran hari ke-2 yaitu tanggal 24 Juni 2015 sehingga terjadi kenaikan debit dari $1,682 \mathrm{~m}^{3} / \mathrm{s}$ menjadi $2,494 \mathrm{~m}^{3} / \mathrm{s}$. Hal ini dapat menjelaskan bahwa terjadinya peningkatan debit pada suatu wilayah DAS karena adanya faktor hujan (intensitas dan lamanya hujan). Menurut Subarkah, 1978 bahwa faktor faktor faktor yang mempengaruhi debit aliran sungai secara umum dapat terbagi 2 yaitu; 


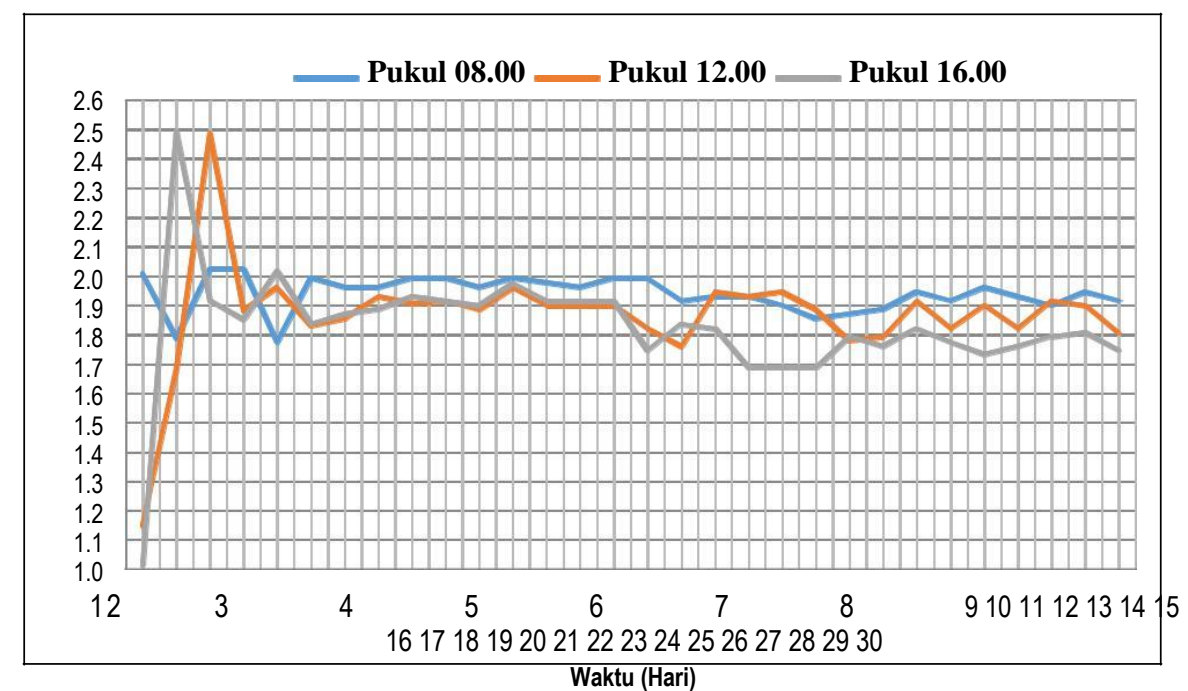

Gambar 3. Pergerakan Debit DAS Tunuo Selama Pengukuran

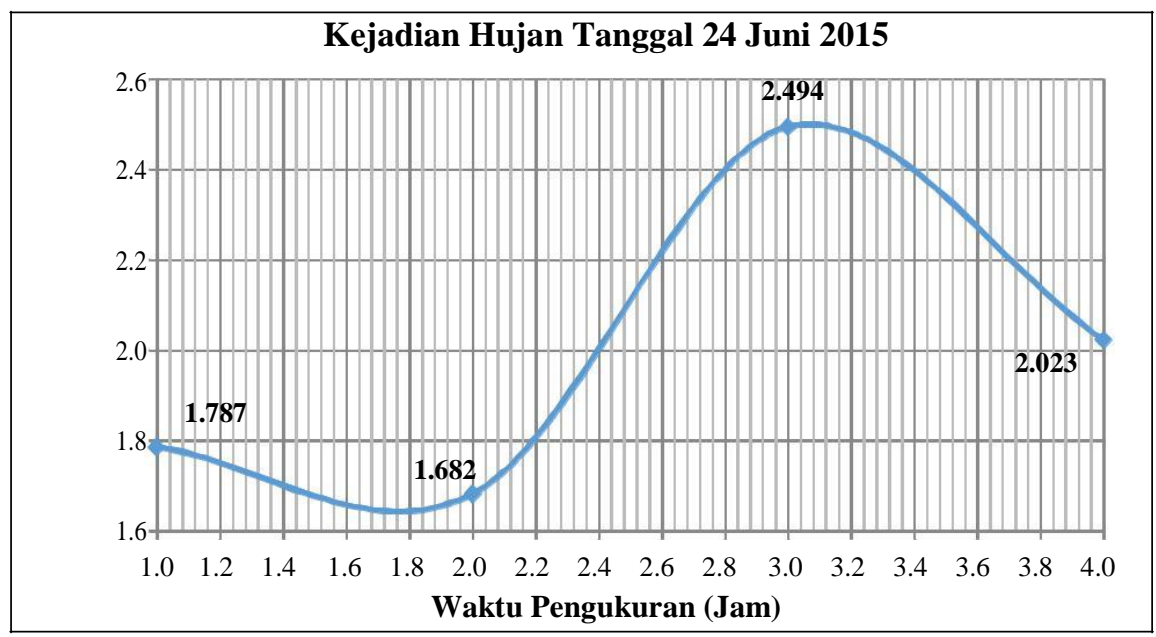

Gambar 4. Grafik Hidrograf Debit Kejadian Hujan Tgl 24 Juni 2015

karakteristik hujan dan karakteristik DAS. Karakteristik hujan dalam hal ini adalah intensitas hujan, lama hujan . Selama pelaksanaan penelitian, bahwa jumlah hari terjadinya hujan hanya terjadi sekali dan pada siang hari sehingga terlihat pada grafik pergerakan debit terjadi kenaikan debit pada pukul 12.00 dan pukul 16.00.

Karakteristik debit aliran yang terjadi pada suatu aliran sungai juga dapat dilihat dengan membuat hidrograf debit. Hidrograf debit adalah suatu grafik yang menggambarkan peristiwa naik turunnya debit yang terjadi pada suatu aliran sungai menurut waktu tertentu tergantung pada sifat hujan dan kondisi biofisik sungai . Sosrodarsono dan Takeda (2003) mengemukakan bentuk hidrograf dapat ditandai dengan tiga sifat pokoknya yaitu yaitu waktu naik (time of rise) debit puncak (peak discharge) dan waktu dasar (base time). Hidrograf debit pada DAS Tunuo dapat dilihat pada Gambar 4.
Berdasarkan hasil analisis diperoleh bentuk hidrograf seperti yang ditunjukkan pada Gambar 4 hidrograf tersebut menunjukkan kejadian hujan pada tanggal 24 Juni 2015 dimana hujan berlangsung pada pagi hari sampai siang hari. Hasil analisis terhadap hidrograf tersebut terhadap waktu dalam hal ini waktu naik (Tp) yang merupakan waktu yang dibutuhkan debit untuk naik menjadi debit puncak (Qp) adalah 5 jam dan waktu yang dibutuhkan debit untuk kembali semula (Tb) adalah sekitar 16 jam. Lamanya waktu naik ini berhubungan dengan kondisi fisik pada wilayah DAS yang meliputi faktor topografi, tanah dan vegetasi (pengelolaan lahan). Sri Harto (1993) menjelaskan bahwa hidrograf pada umumnya dipengaruhi oleh sifat fisik DAS, sifat vegetasi penutup lahan dan distribusi kejadian hujan.Karakteristik debit dengan waktu lama pada aliran sungai tersebut menggambarkan bahwa kondisi topografi pada 
wilayah DAS Tunuo umumnya relatif datar dan landai sehingga waktu yang dibutuhkan oleh air hujan untuk sampai ke sungai utama baik melalui permukaan tanah maupun aliran bawah tanah cukup lama untuk sampai ke sungai utama dan menjadi debit aliran. Disamping itu dengan kondisi topografi yang datar maka akan memberi-kan waktu yang cukup lama untuk proses infiltrasi.

Faktor vegetasi dalam hal ini adalah penggunaan lahan pada DAS juga turut berpengaruh terhadap hidrograf tenatng karakteristik debit aliran pada sungai. Peranan vegetasi pada wilayah DAS adalah sebagai penahan dan penghambat daya rusak oleh butir - butir air hujan terhadap permukaan tanah, kemudian vegetasi juga dapat melakukan proses transpirasi sehingga dapat mengurangi kandungan air tanah, dan pengaruh akar tanaman dan kegiatan biologi yang berhubungan dengan proses infiltrasi tanaman.

Berdasarkan analisis secara spasial penutu-pan lahan pada DAS Tunuo didominasi oleh kebun campuran sebesar 51,6\%, hutan $46,4 \%$, pemukiman $1,1 \%$, semak belukar $0,1 \%$ dan lahan terbuka $0,8 \%$. Komposisi hutan dan kebun campuran yang dominan ini mempengaruhi waktu naik (Tp) menjadi lama karena dengan tutupan lahan yang rapat akan mengakibatkan proses intersepsi, evaporasi, dan transpirasi meningkat sehingga air yang hilang sebelum masuk kedalam aliran sungai menjadi lebih besar sehingga waktu yang dibutuhkan air hujan untuk sampai ke sungai utama. Ward (1974 dalam Arsyad 1989) mengemukakan bahwa pada kondisi alami atau sedikit berubah, pengaruh kerapatan vegetasi lebih penting daripada pengaruh jenis vegetasi, karena dengan adanya peningkatan kerapatan vegetasi akan meningkat-kan kapasitas infiltrasi terutama dari golongan tanaman berkayu.

\section{KESIMPULAN}

Beberapa kesimpulan dalam penelitian :

1. Karakteristik debit aliran pada DAS Tunuo memiliki waktu naik (Tp) membutuhkan waktu selama 5 jam, sedangkan waktu dasar (Tb) adalah sekitar 16 jam

2. Faktor biofisik DAS Tunuo yaitu topografi, vegetasi (penutupan lahan) dan tanah berperan dalam menghambat kecepatan curah hujan.

\section{DAFTAR PUSTAKA}

Arsyad, S., 1989. Konservasi Tanah dan Air. Insititut Pertanian Bogor Press. Bogor.

Arsyad, S., 2010. Konservasi Tanah dan Air. Insititut Pertanian Bogor Press. Bogor.

Asdak, C. 2010. Hidrologi dan Pengelolaan Daerah Aliran Sungai. Gadjah Mada University Press, Yogyakarta

Cahyadi, E. 2002. Dampak Penerapan Sistem Silvikultur Tebang Pilih Tanam Indonesia terhadap Karakteristik Hidrologi. Laju Erosi dan Sedimentasi di Sub DAS Keramu DAS Barito Propinsi Kalimantan Tengah. Skripsi. Jurusan Manajemen Hutan Fakultas Kehutanan Institut Pertanian Bogor. Bogor.

Chow, V. T, 1964. Handbook of Applied Hydrology. McGraw-Hill, Inc. United States of America.

Farida, Van Noordwijk, M., 2004. Analisis Debit Sungai Akibat Alih Guna Lahan dan Aplikasi Model Genriver Pada DAS Way Besai, Sumberjaya. World Agroforestry Centre - ICRAF Se ASIA. PO Box 161, Bogor.

Gordon ND, McMahon T.A., Finlayson B.L., 1992. Stream Hydrology An Introduction For Ecologist. John Wiley \& Sons.

Harto, S. 1993. Analisis Hidrologi. Penerbit PT Gramedia Pustaka Utama. Jakarta.

Nasrullah, B.K. 2002. Analisis Alih Fungsi Lahan dan Keterkaitannya Dengan Karakteristik Hidrologi DAS Krueng Aceh. Jurnal Tanah dan Iklim No . 3 Tahun 2010, Balai Penelitian Agroklimat dan Hidrologi. Bogor.

Mappangaja, B.1983. The Improvised Current Meter For Disharge Measurement. Submitted to The Faculty of The Graduate School, University of The Philippinnes at Los Banos

Sosrodarsono, S., Kensaku, T. 2003. Hidrologi Untuk Pengairan (cetakan kedelapan). PT.Pradnya Paramita, Jakarta.

Subarkah,I., 1978. Hidrologi Untuk Perencanaan Bangunan Air. Penerbit Idea Dharma, Bandung.

Saenullah, 2012. Fluktuasi Debit Harian Pada Sungai Takapala dan Sungai Balli Parang, Sub DAS Lengkese, DAS Jeneberang Hulu. Skripsi. Fakultas Kehutanan, Universitas Hasanuddin. Makassar. 